Division of Geological \& Geophysical Surveys

REPORT OF INVESTIGATION 2011-1

\title{
A PALEOSEISMIC STUDY ALONG THE CENTRAL DENALI FAULT, CHISTOCHINA GLACIER AREA, SOUTH-CENTRAL ALASKA
}

by

R.D. Koehler, S.F. Personius, D.P. Schwarz, P.J. Haeussler, and G.G. Seitz

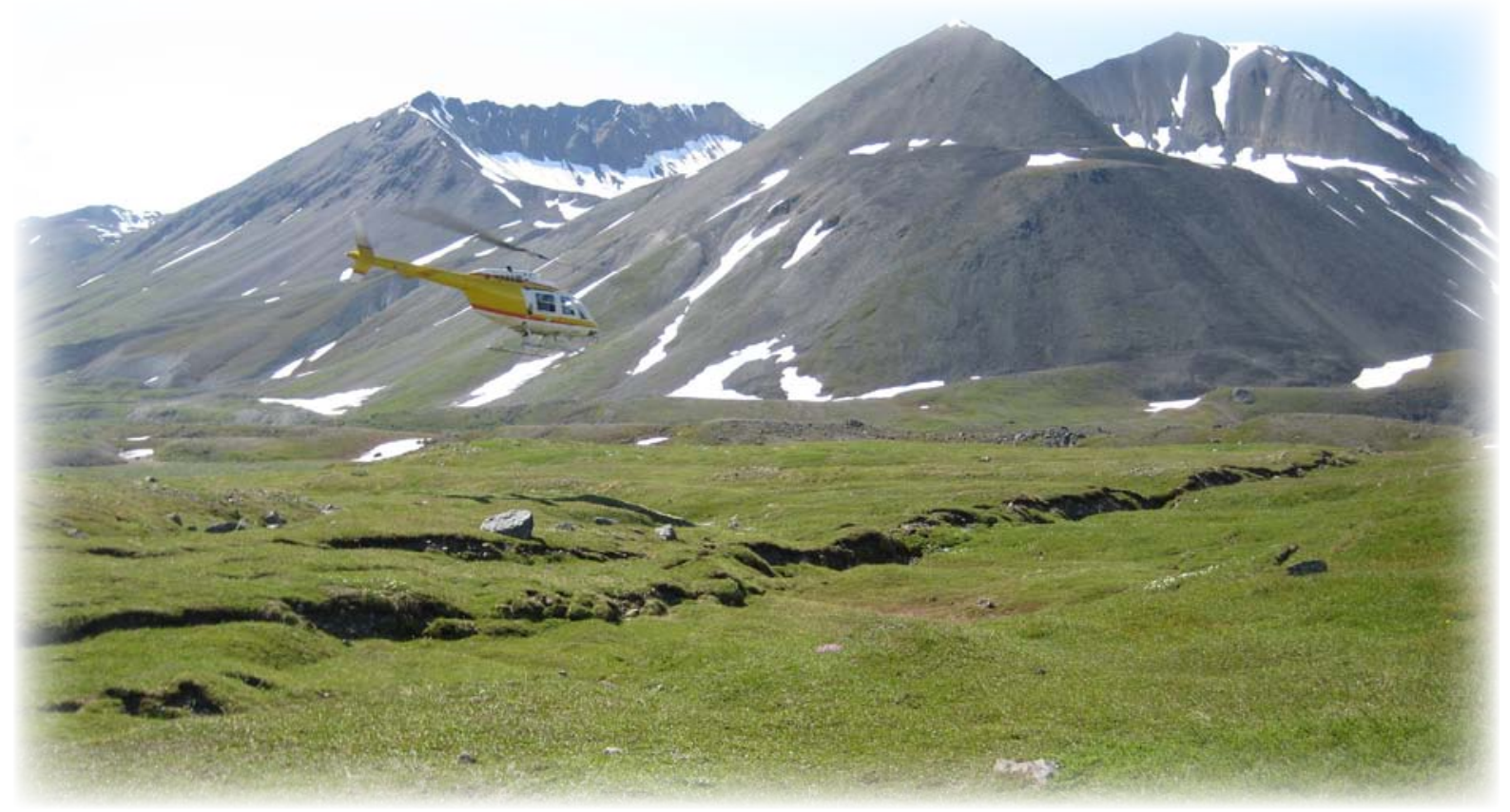

Photograph of surface rupture scarps related to the 2002 Denali fault earthquake near Chistochina Glacier, Alaska. Scarps are shadowed and extend across the center of the photo.

March 2011

Released by

STATE OF ALASKA

DEPARTMENT OF NATURAL RESOURCES

Division of Geological \& Geophysical Surveys

3354 College Rd.

Fairbanks, Alaska 99709-3707 


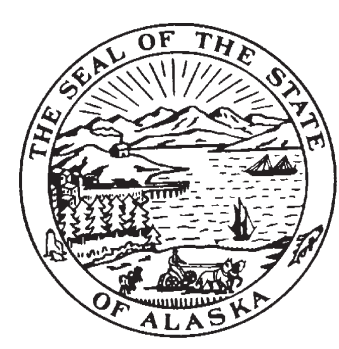

STATE OF ALASKA

Sean Parnell, Governor

\section{DEPARTMENT OF NATURAL RESOURCES}

Daniel S. Sullivan, Commissioner

\section{DIVISION OF GEOLOGICAL \& GEOPHYSICAL SURVEYS Robert F. Swenson, State Geologist and Director}

Publications produced by the Division of Geological \& Geophysical Surveys can be examined at the following locations. To order publications, contact the Fairbanks office.

\section{Alaska Division of Geological \& Geophysical Surveys \\ 3354 College Rd., Fairbanks, Alaska 99709-3707 \\ Phone: (907) 451-5020 Fax (907) 451-5050 \\ dggspubs@alaska.gov www.dggs.alaska.gov}

\begin{abstract}
Alaska State Library
State Office Building, 8th Floor

3354 College Road

Juneau, Alaska 99811-0571

Elmer E. Rasmuson Library University of Alaska Fairbanks Fairbanks, Alaska 99775-1005
\end{abstract}

\author{
Alaska Resource Library \& Information \\ Services (ARLIS) \\ 3150 C Street, Suite 100 \\ Anchorage, Alaska 99503 \\ University of Alaska Anchorage Library \\ 3211 Providence Drive \\ Anchorage, Alaska 99508
}

This publication released by the Division of Geological \& Geophysical Surveys was produced and printed in Fairbanks, Alaska, at a cost of \$2 per copy. Publication is authorized by Alaska Statute 41, which charges the division "to determine the potential of Alaskan land for production of metals, minerals, fuels, and geothermal resources; the location and supplies of groundwater and construction materials; the potential geologic hazards to buildings, roads, bridges, and other installations and structures; and shall conduct such other surveys and investigations as will advance knowledge of the geology of Alaska.” 


\section{CONTENTS}

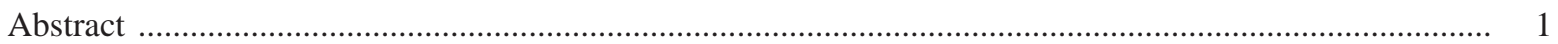

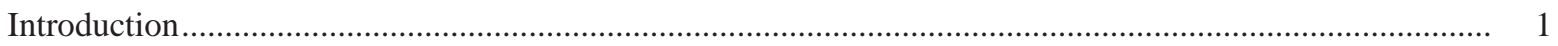

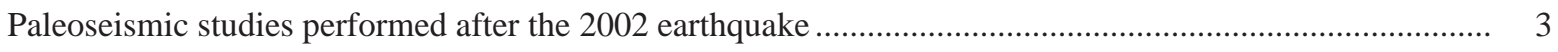

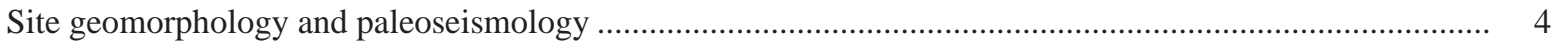

Offset glacial moraines, stream channels, and secondary deformation .................................................. 9

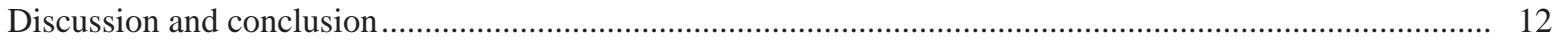

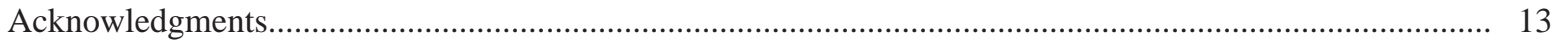

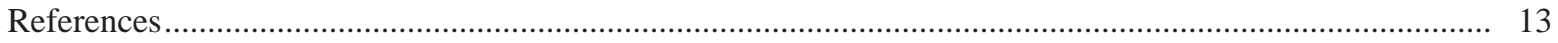

TABLE

Table 1. Radiocarbon data from Slate Creek site, trench SLC-T1, Denali fault west of Chistochina Glacier.

\section{FIGURES}

Figure 1. Location map showing topography of the Alaska Range and the 2002 Denali fault earthquake rupture

2. The Slate Creek site and tectonic geomorphic features shown on air photographs collected by the U.S. Geological Survey after the 2002 Denali fault earthquake.....

3. Tectonic geomorphic features along the 2002 Denali fault surface rupture trace near the paleoseismic trench site

4. Photomosaic of Denali fault, Slate Creek site, trench SLC-T1, and log of the exposure

5. Photograph showing the main fault zone after the wall was cut back $\sim 0.25 \mathrm{~cm}$

6. Air photograph of the Boulder Moraine site near the Middle Fork Chistochina River showing

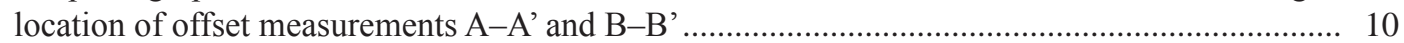

7. Retrodeformation of offset moraines at the Boulder Moraine site .......................................... 11

8. Enlarged photo of western side of the Slate Creek site....................................................... 12

\section{APPENDIX}





\title{
A PALEOSEISMIC STUDY ALONG THE CENTRAL DENALI FAULT, CHISTOCHINA GLACIER AREA, SOUTH-CENTRAL ALASKA
}

\author{
by \\ R.D. Koehler ${ }^{1}$, S.F. Personius², D.P. Schwarz ${ }^{3}$, P.J. Haeussler ${ }^{4}$, and G.G. Seitz ${ }^{5}$
}

\begin{abstract}
In the Chistochina Glacier area of south-central Alaska, the active trace of the Denali fault is well defined by prominent tectonic geomorphology, including scarps, grabens, and mole tracks associated with the $2002 \mathrm{M}_{\mathrm{w}}=7.9$ Denali fault earthquake. Interpretation of a trench excavated across the 2002 rupture trace places a constraint on the timing of the penultimate earthquake to after 550 to $660 \mathrm{yr}$ before 2002, consistent with other paleoseismic studies along the central Denali fault. Field measurement of offset moraine deposits and use of existing geochronologic data is the basis to estimate a minimum latest Pleistocene slip rate of $8-14 \mathrm{~mm} / \mathrm{yr}$.
\end{abstract}

\section{INTRODUCTION}

The intracontinental right-lateral Denali fault (fig. 1) extends over $2,000 \mathrm{~km}$, including $\sim 500 \mathrm{~km}$ along the arcuate southern margin of the Alaska Range in south-central Alaska (St. Amand, 1957; Grantz, 1966; Richter and Matson, 1971). The fault was the source of the $2002 \mathrm{M}_{\mathrm{w}}=7.9$ Denali fault earthquake, one of the seven largest continental strike-slip earthquakes since 1900 (Schwartz, 2006), which ruptured $340 \mathrm{~km}$ along the Susitna Glacier thrust, Denali fault, and Totschunda fault (Eberhart-Phillips and others, 2003; Ji and others, 2002; Frankel, 2004; Haeussler and others, 2004). The fault accommodates a component of slip related to the approximately 4.9-5.7 $\mathrm{cm} / \mathrm{yr}$ of relative oblique convergence between the Pacific/Yakutat and North American plates, the remainder of which is accommodated by the subduction interface, foreland fold and thrust belt structures, and other smaller lateral slip faults. Several lithotectonic terranes that accreted onto the North American craton in Phanerozoic time are juxtaposed across the fault (Plafker and Berg, 1994) and attest to the fault's long-term displacement history. Total post-mid Cretaceous cumulative right-lateral displacement across the fault has been estimated to be between 300 and $400 \mathrm{~km}$ (Nokleberg and others, 1985; Lowey, 1998; Lanphere, 1978). Although the dominant sense of slip on the Denali fault is dextral, drainages of the Nenana and Delta rivers flow north across the axis of the Alaska Range, indicating that they are antecedent to regional uplift. Additionally, the Pliocene Nenana Gravel outcrops on both sides of the range and was deposited by north-flowing rivers (Capps, 1912; Wahrhaftig, 1958; Wahrhaftig and others, 1969; Thoms, 2000; Ridgway and others, 2007). Thus, the Denali fault system is characterized by restraining transpressional geometry with associated thrust faults and folds that have played a significant role in the deformation and uplift of the Alaska Range. Further details on the neotectonic framework of the Alaska Range and the Denali fault are compiled in Haeussler (2008).

Plafker and others (1994) divided the Denali fault into sections based on the age of most recent faulted deposits. Within the section of the fault that extends from the vicinity of Mt. McKinley eastward to the area of the Chisana River in eastern Alaska (the western part of the Muldrow-Alsek section), Quaternary activity is evidenced by nearly continuous scarps in glacial deposits. Early studies of offset features in this area indicate late Pleistocene to Holocene slip rates of 11-35 mm/yr (Richter and Matson, 1971; Hickman and others, 1977; Plafker and others, 1977). Cosmogenic exposure age analyses of offset glacial deposits in two separate studies indicate that the latest Pleistocene-Holocene slip rate is around 12 to $13 \mathrm{~mm} / \mathrm{yr}$ and suggest a slight decrease in rate to the west (Matmon and others, 2006; Mériaux and others, 2009). These observations are generally consistent with geodetic (6.5-9 $\mathrm{mm} / \mathrm{yr}$ ) and InSAR (10 mm/yr) measurements of strain accumulation (Fletcher, 2002; Biggs and others, 2007), a westward decrease in cumulative slip (Plafker and Berg, 1994), as well as westward diminishing average slip in the 2002 earthquake (Haeussler and others, 2004; Taylor and others, 2008).

${ }^{1}$ Alaska Division of Geological \& Geophysical Surveys, 3354 College Rd., Fairbanks, Alaska 99709-3707; rich.koehler@alaska.gov ${ }^{2}$ U.S. Geological Survey, PO Box 25046, MS966, Denver, CO 80225

${ }^{3}$ U.S. Geological Survey, 345 Middlefield Rd., MS977, Menlo Park, CA 94025

${ }^{4}$ U.S. Geological Survey, 4200 University Dr., Anchorage, AK 99508

${ }^{5}$ Seitz Consulting, 1375 Kelton Ave, \#102, Los Angeles, CA 90024 


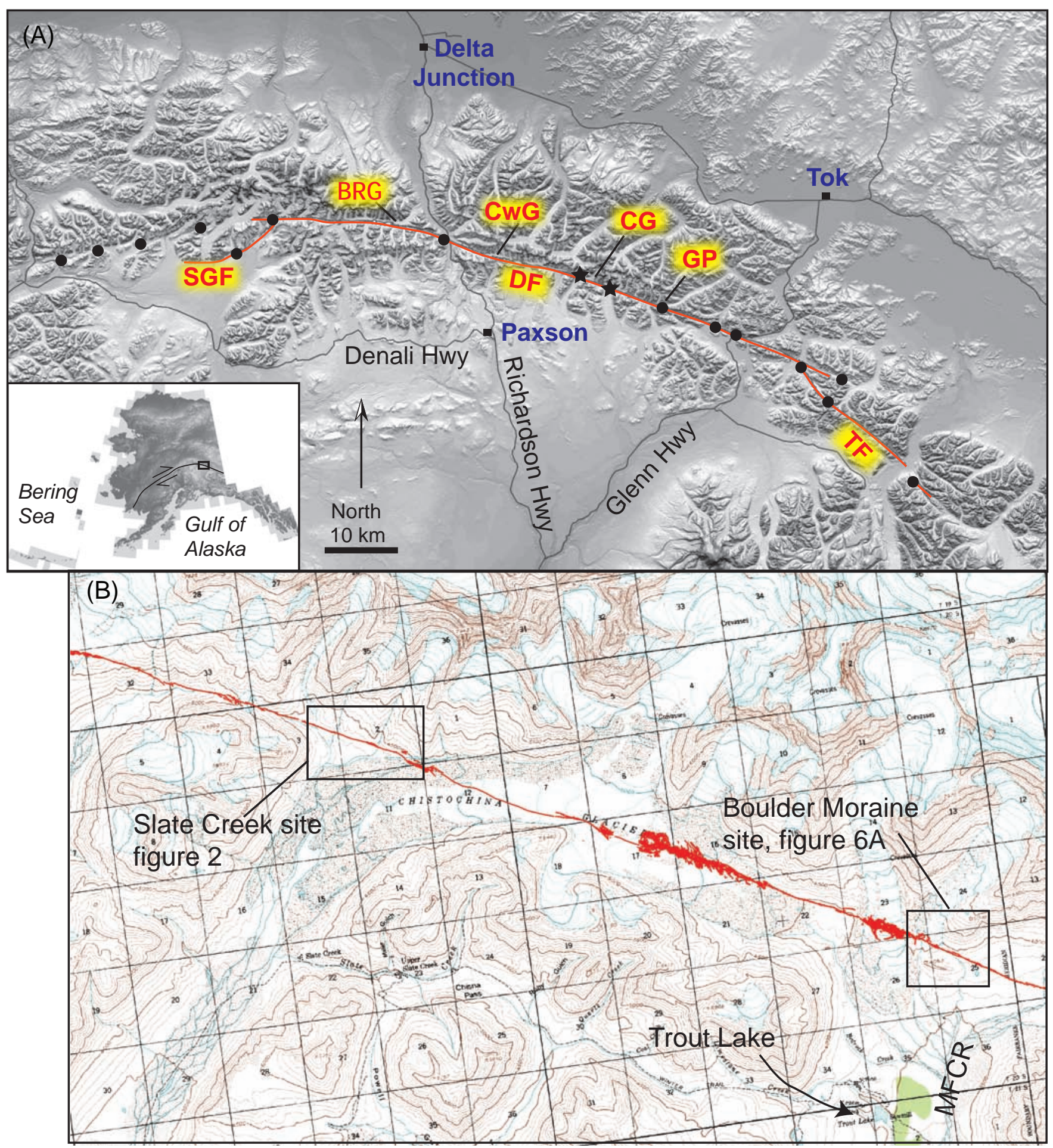

Figure 1. (A) Location map showing topography of the Alaska Range and the 2002 Denali fault earthquake rupture (red). Slate Creek paleoseismic trench sites and Boulder Moraine offset site are labeled with black stars on the west and east sides of Chistochina Glacier, respectively. Previous paleoseismic studies are approximately located and marked with black dots. Area of enlarged DEM is denoted by tiny black rectangle on inset map of Alaska. DF = Denali fault; SGF = Susitna Glacier fault; $T F=$ Totschunda fault; $C w G=$ Canwell Glacier; $C G=$ Chistochina Glacier; BRG = Black Rapids Glacier; GP = Gillett Pass. (B) Topographic map of the Chistochina Glacier area showing 2002 rupture trace (red) and locations of the Slate Creek and Boulder Moraine sites (black boxes). MFCR = Middle Fork Chistochina River. 
Prior to the 2002 earthquake, little information was known about the fault's late Quaternary behavior; however, a concerted effort by multiple workers was initiated in the years after the event to understand the paleoseismic history of the Denali and associated faults (for example, Plafker and others, 2006; Carver and others, 2004; Schwartz and others, 2003; Crone and others, 2004). As a contribution to these efforts, we report the results of a paleoseismic trench excavation across the 2002 Denali fault surface rupture trace at the "Slate Creek site" and new measurements of offset glacial moraines east of the Chistochina Glacier at the "Boulder Moraine site." The investigation focused on obtaining information on the earthquake history of the fault and independent validation of recently established latest Pleistocene slip rates. The investigation was performed in conjunction with the Mentasta-Slana STATEMAP project jointly funded by the State of Alaska and the U.S. Geological Survey. The results contribute to the ongoing efforts by the Denali fault earthquake geology working group (Schwartz and others, 2003) to better characterize the Quaternary behavior of the Denali fault.

\section{PALEOSEISMIC STUDIES PERFORMED AFTER THE 2002 EARTHQUAKE}

The 2002 surface rupture initiated on the Susitna Glacier thrust along the southern margin of the Alaska Range merged with the main trace of the Denali fault and propagated eastward, until finally diverting southeast onto the Totschunda fault (Ji and others, 2002). Aerial and field reconnaissance of the surface rupture performed immediately after the earthquake culminated in one of the most thorough compilations of coseismic deformation and slip distribution to date, including documentation of rupture in glacial ice that is no longer preserved, and measurement of 132 piercing points (Haeussler and others, 2004). In general, the slip distribution is asymmetric with $\sim 2$ $\mathrm{m}$ on the western end increasing to the east to $\sim 9 \mathrm{~m}$ near the junction of the Denali and Totschunda faults, and decreasing to less than $3 \mathrm{~m}$ along the Totschunda fault (Haeussler and others, 2004). Initial paleoseismic studies have been performed on all three faults that were involved in the 2002 Denali fault earthquake. The locations of these studies are shown on figure 1.

The 48-km-long rupture on the Susitna Glacier thrust fault included rupture on south-directed main thrusts and north-directed back thrusts and was characterized by maximum and average surface offsets of $6.7 \mathrm{~m}$ and $1.5-2.5 \mathrm{~m}$, respectively (Crone and others, 2004). Crone and others (2004) recognized superposition of 2002 ruptures on large old scarps, but evidence for pre-2002 ruptures along the Susitna Glacier thrust is limited. Along an older scarp reported by Crone and others (2004), the 2002 surface rupture exposed a volcanic ash in the hangingwall from which they infer one or more paleoearthquakes that postdate the ash (Susitna Glacier fault [SGF], fig. 1). The ash may correlate with either the Jarvis Creek ash (3.6 ka) or Hayes tephra set H (Begét and others, 1991; Riehle, 1994), indicating a late Holocene age for the penultimate event (Personius and others, 2010).

Along the Denali fault, surface rupture extended eastward for $226 \mathrm{~km}$ (including $\sim 10 \mathrm{~km}$ west of the intersection of the Susitna Glacier and Denali faults) and was characterized by a left-stepping, nearly continuous rupture pattern with average right-lateral displacements of 4.5-5.1 m (Haeussler and others, 2004). Observations of the amount of paleo-slip along the 2002 rupture trace at three sites between the Black Rapids Glacier and Gillett Pass and three sites east of Gillett Pass indicate that penultimate slips were similar to the displacement in 2002, around $5 \mathrm{~m}$ and $7-8 \mathrm{~m}$, respectively (Schwartz and others, 2003). Plafker and others (2006) present results from cuts along the west bank of the Delta River and suggest that two paleoearthquakes occurred, one 310-460 yr BP and the other 650-780 yr BP. Carver and others (2004) interpreted healed splits and scars in old trees damaged in the 2002 event as evidence for a prior earthquake. Based on historical and tree-ring data, Carver and others (2004) inferred that the damaged trees are the surface manifestation of an earthquake that occurred in July 1912. Additional trenching performed by the Denali Fault Earthquake Geology Working Group (Schwartz and others, 2003) has provided earthquake chronology data for the section of the fault that ruptured in 2002, as well as sections to the west and east. These data indicate that the 2002 rupture section produced an earthquake sometime between 340 and $590 \mathrm{yr}$ b02 (before 2002) and another between 705 and 1,070 yr b02. The Denali fault west of the 2002 rupture produced earthquakes between 100 and $370 \mathrm{yr}$ b02 and between 550 and $680 \mathrm{yr}$ b02. East of the junction between the Denali and Totschunda faults, the Denali fault ruptured in three paleoearthquakes between 100 and $346 \mathrm{yr}$ b02, $\geq 550$ and $680 \mathrm{yr} \mathrm{b02}$, and $\leq 1,010$ and $1,220 \mathrm{yr}$ b02.

The final $66 \mathrm{~km}$ of the rupture on the Totschunda fault was associated with dextral offsets that averaged $1.6-1.8 \mathrm{~m}$ (Haeussler and others, 2004). Schwartz and others (2003) indicate that paleo-offsets measured along the Totschunda fault are similar to those that occurred in 2002. Trenching studies on the Totschunda fault suggest the occurrence of paleoearthquakes between 580 and $700 \mathrm{yr}$ b02 and between 1,180 and 1,390 yr b02 (Schwartz and others, 2003). 


\section{SITE GEOMORPHOLOGY AND PALEOSEISMOLOGY}

This study focuses on an approximately $14 \mathrm{~km}$ section of the 2002 Denali fault rupture trace near Chistochina Glacier. We evaluated stereo color-infrared aerial photographs and performed helicopter reconnaissance and field mapping to identify a suitable site for paleoseismic investigation. At the Slate Creek site, the fault is a relatively simple left-stepping linear trace that is prominently expressed by uphill- and downhill-facing scarps, linear troughs, and right-laterally displaced stream channels and glacial deposits (fig. 2). The trench site, located at UTM coordinates $609948 \mathrm{E}, 615848950 \mathrm{~N}$ (figs. 2A and 2B), encompasses a ground moraine characterized by continuous unvegetated surface scarps. Directly west of the trench site the fault is expressed by a large mole track across an alluvial cobble channel and a $\sim 15-\mathrm{m}$-wide graben (figs. 3A and 3B). Side slopes on both sides of the fault are characterized by pervasive ground cracking oriented parallel and acute to the fault trend. Alignments of boulders on the surface may be the result of cryoturbation processes operating along paleoearthquake surface cracks. East of the trench site the fault cuts oblique to a large lateral moraine (fig. 2A). The crest of the moraine, as well as an inset lateral moraine, is right-laterally offset. An alignment of boulders near the crest of the inset lateral moraine is offset $\sim 10 \mathrm{~m}$ and likely the result of multiple earthquakes (fig. 3C). Farther east the fault parallels the side slope of the lateral moraine and projects into the Chistochina Glacier, where it extends across the ice field and is no longer preserved. At multiple locations in the site vicinity, stream channels are displaced about $5 \mathrm{~m}$ across 2002 rupture breaks, consistent with observations made during post-earthquake surveys elsewhere along the fault (Haeussler and others, 2004).

Two trenches were hand excavated normal to the fault, trench SLC-T1 and SLC-T2/3 (fig. 2). A photomosaic and sketch of the western wall of trench SLC-T1, logged at a scale of 1 in:0.5 m, is shown in figure 4. Unit descriptions for stratigraphic deposits exposed in the trench are contained in Appendix A. The trench wall was cut back $0.25 \mathrm{~m}$ to investigate details within the main fault zone along the north side of the exposure. A photograph of the main fault zone and an enlarged sketch $\log$ at a scale of $1 \mathrm{in}: 0.25 \mathrm{~m}$ is shown in figure 5 . The trench exposed a basal glacial till (Unit 1), consisting of greenish black clayey sand with $\sim 30$ percent gravel and cobbles. Unit 2 consists of well bedded, moderately to well sorted gravel and sandy gravel that fines upward to coarse sand. Unit 3 conformably overlies Unit 2, and consists of finely laminated, well sorted medium to fine sand that grades upward into silt with trace gravels. A layer of clast-supported angular cobbles averaging $3-6 \mathrm{~cm}$ in diameter (Unit 4 ) overlies Unit 3 in the center of the exposure. These cobbles may be lag cobbles from deglaciation. The exposure is capped by the active peat mat (Unit 7) except where faults have broken the surface. A dark brown fibrous peat (Unit 5) is backtilted within the fault zone, rests on Unit 3, and is buried by loose sand and gravel (Unit 6).

A total of six faults were identified, all of which break the entire stratigraphic section to the surface, indicating rupture during the 2002 event (faults labeled F1-F6 on fig. 4). Deformation across the exposed zone of faults has created a subtle linear topographic swale on the surface. Small offsets and stratigraphic thickness variations across individual faults, such as that observed across faults F2, F3, and F4, are characteristic features of strike-slip motion. Local south-side-up motion across fault F1 has resulted in folding of the generally flat-lying stratigraphy. A continuous, unvegetated surface scarp is coincident with fault F6, which is characterized by south-side-down displacement and vertically aligned clasts. Thrust motion across the northern splay of fault F5 is indicated by the juxtaposition of the base of Unit 5 peat against peat in growth position at the top of Unit 5 across a distinct parting (fig. 5).

Faults F1-F6 all break the entire stratigraphic package to the surface, providing evidence for rupture during the 2002 earthquake, event E1. Evidence for prior paleoearthquakes is not apparent across faults F1-F4, but stratigraphic relations preserved between faults F5 and F6 provide evidence for at least one and possibly two paleoearthquakes. The penultimate event, paleoearthquake E2, is recorded by a peat deposit (Unit 5) that represents a former ground surface and is backtilted against fault F6. The peat deposit is buried by Unit 6, interpreted to be fault-scarp colluvium derived from Units 2 and 3 that eroded off a free face created in the penultimate event. Thus, the penultimate event (E2) occurred after the deposition of peat (Unit 5) and prior to burial by the colluvium (Unit 6). Preliminary radiocarbon analysis of this peat suggests that the penultimate event occurred after AD 1290-1400 (after 660-550 yr b02) (table 1). A block of glacial till in Unit 3 (fig. 5) that may have eroded off a paleoscarp provides possible indirect evidence for an older paleoearthquake, event E3. It is likely that additional paleoearthquakes ruptured through the site. However, we infer that these events are not recorded in the stratigraphy due to the thin stratigraphic package $(\sim 0.5 \mathrm{~m})$ and the possibility of repeated rupture along individual faults (fault $\mathrm{F} 6$ ) that would overprint and/or destroy evidence of older earthquakes. Additionally, complex deformation related to the ripping and rolling of the peat mat during shearing may obscure evidence of additional earthquakes in the main fault zone. 

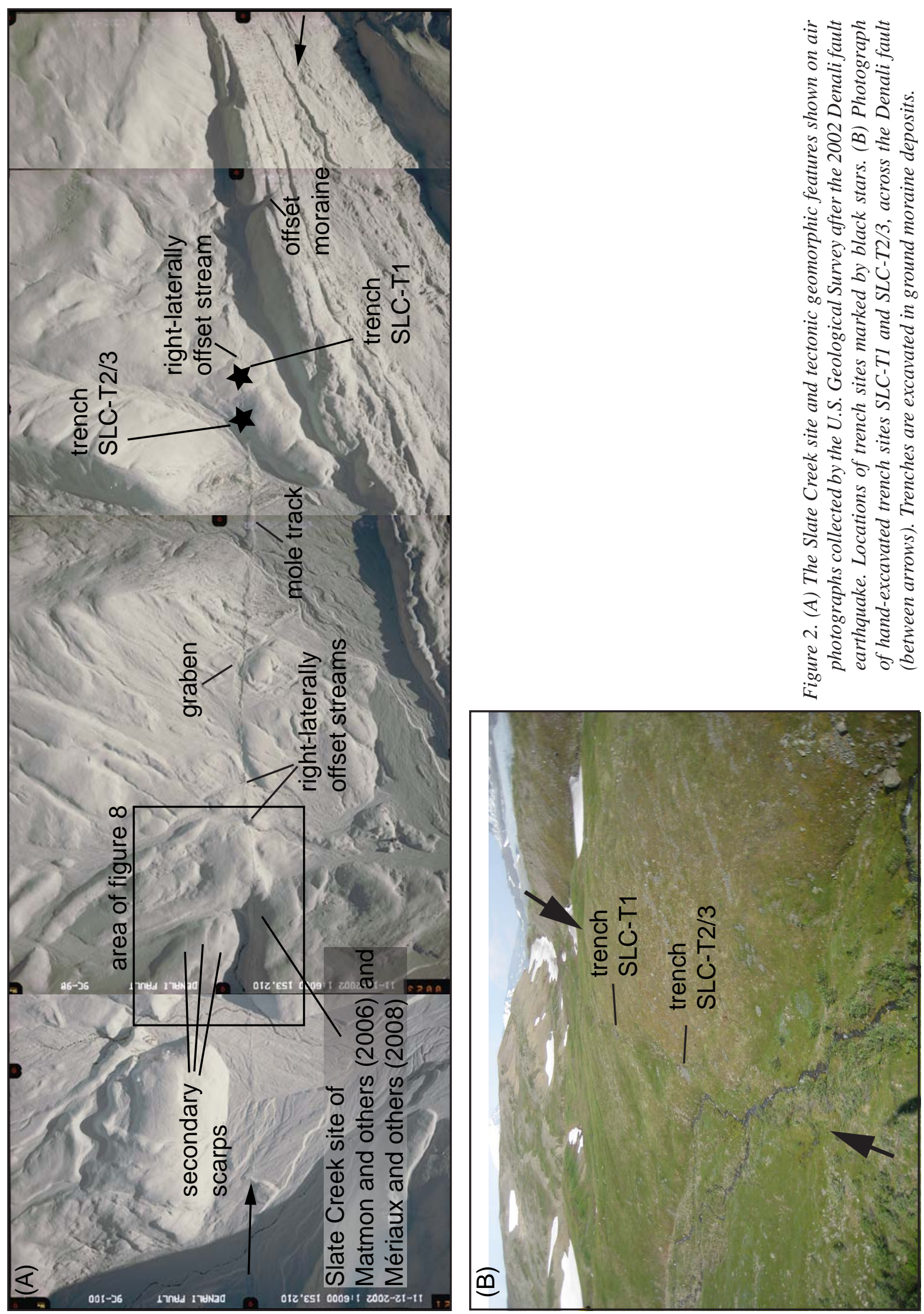


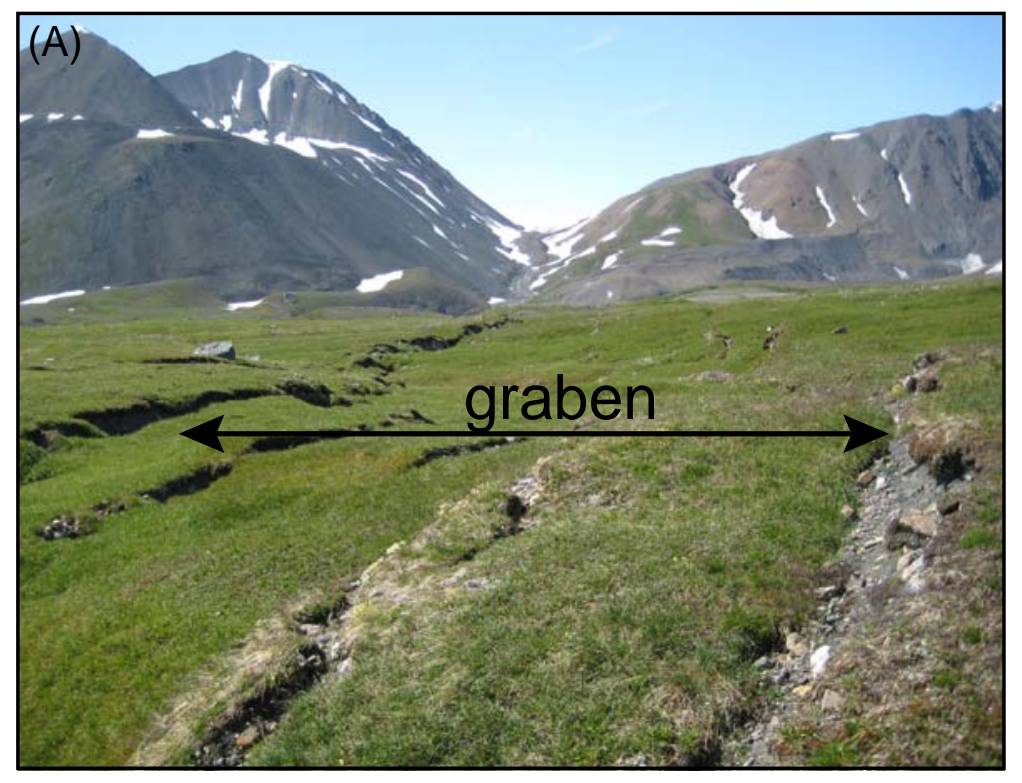

Figure 3. Tectonic geomorphic features along the 2002 Denali fault surface rupture trace near the paleoseismic trench site including (A) graben, (B) moletrack in an alluvial channel, and (C) offset boulder line (between arrows) on moraine crest. See figure 2 for locations.
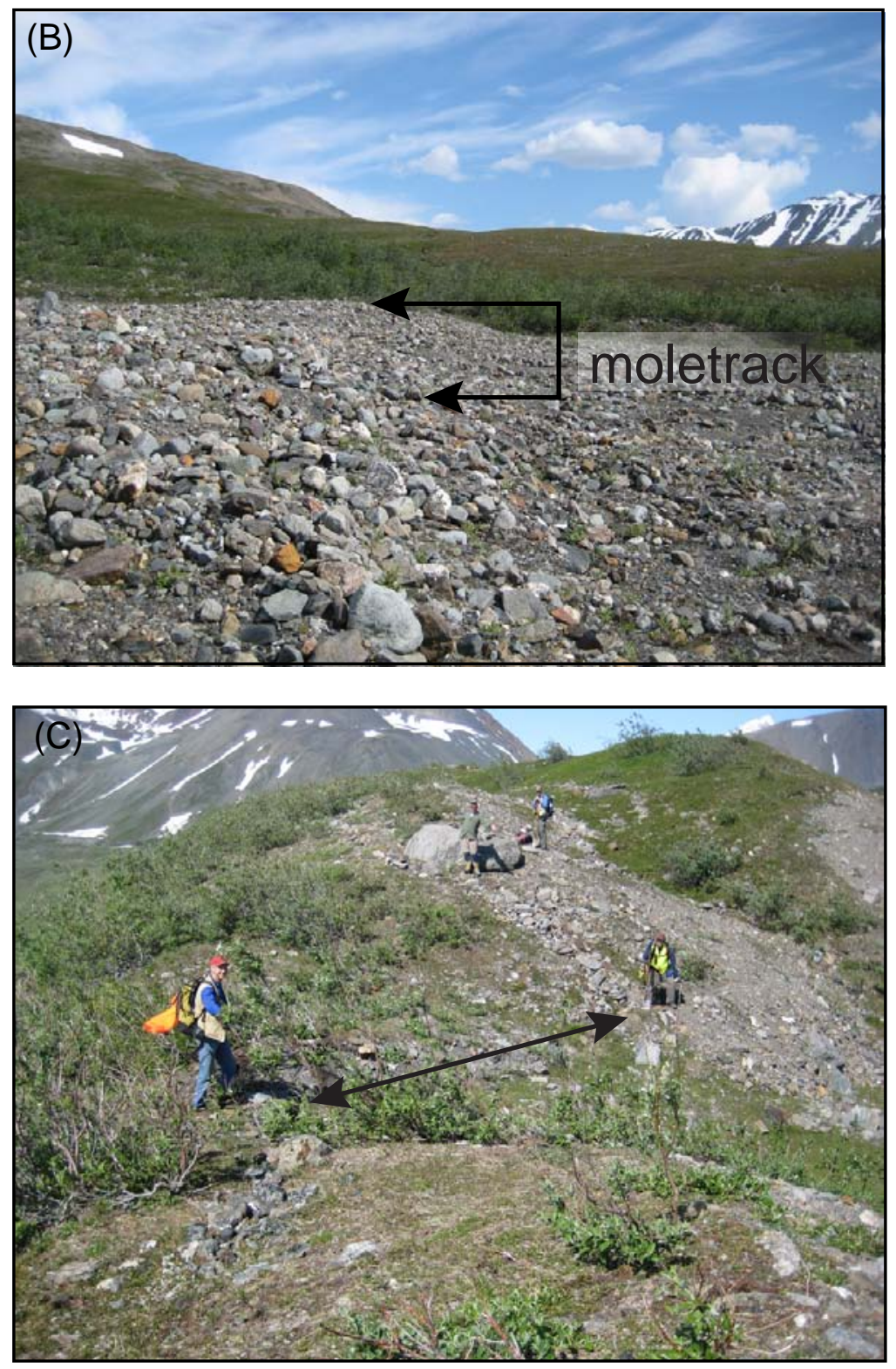


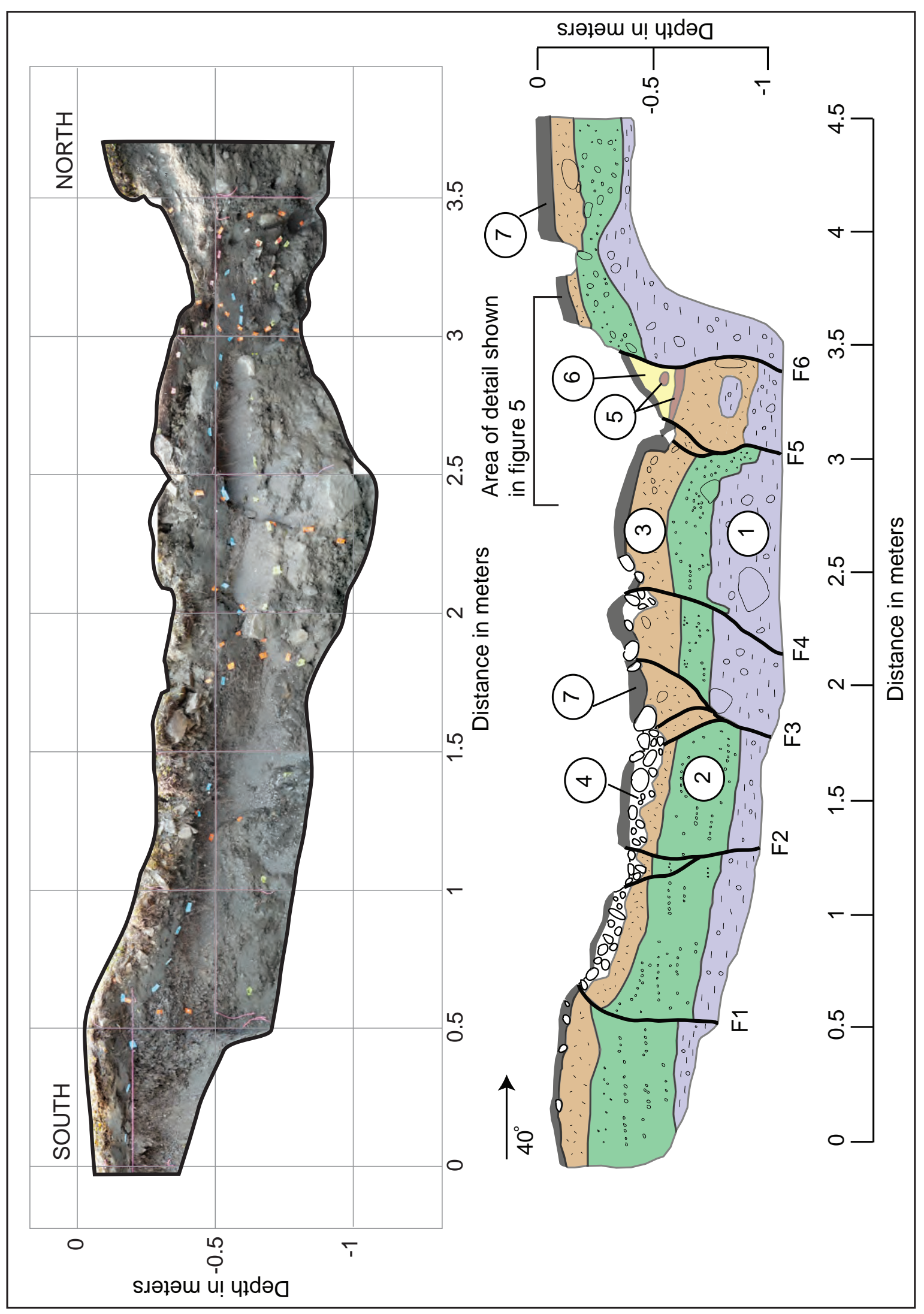

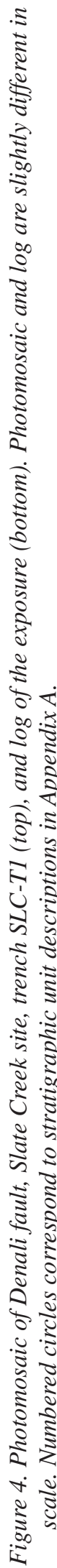




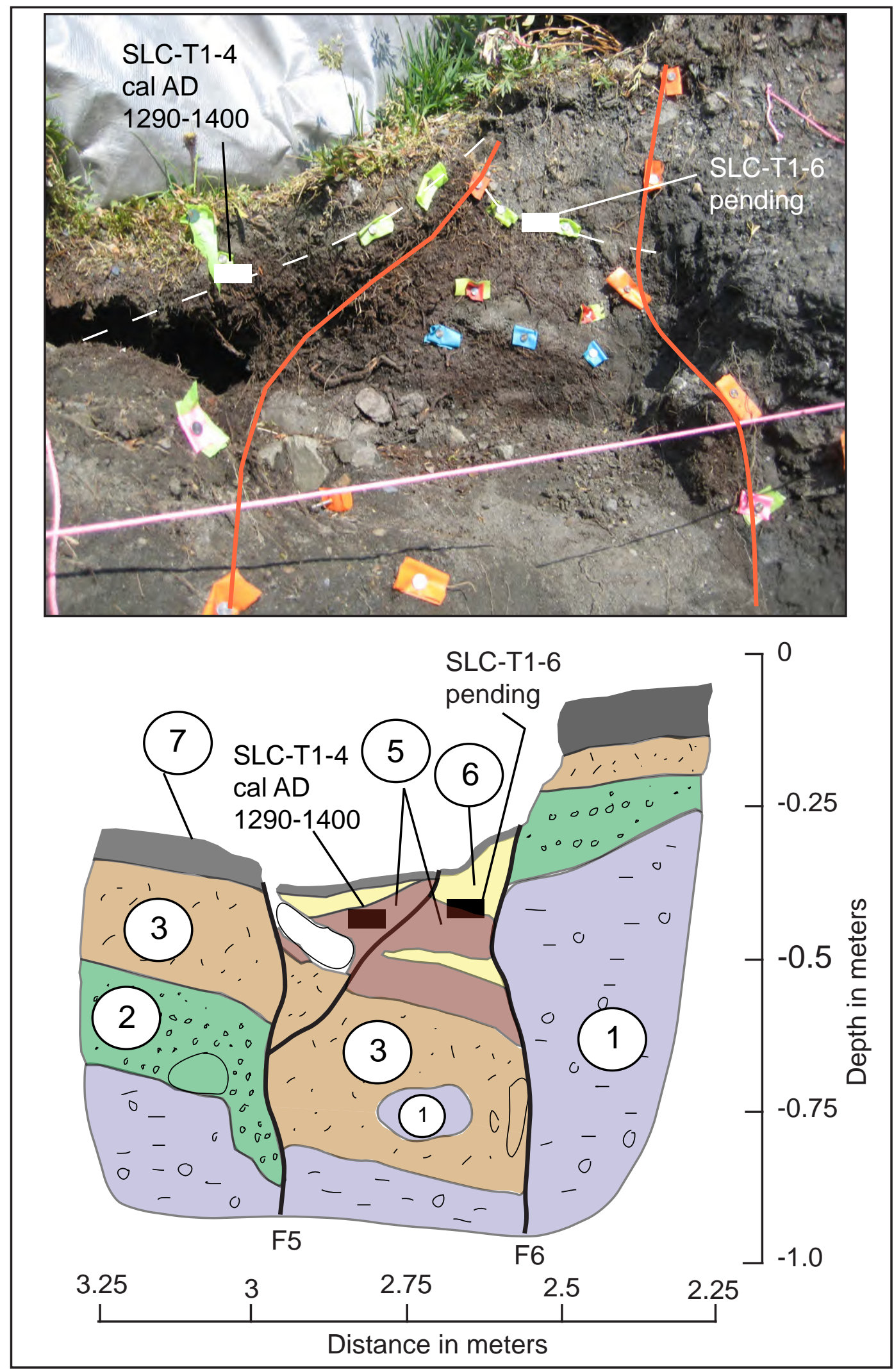

Figure 5. Photograph at top shows the main fault zone after the wall was cut back $\sim 0.25 \mathrm{~cm}$. Dashed white line indicates top of peat (Unit 5) that is buried by colluvium (Unit 6). Red lines are faults. Log below the photo shows the interpretation of an area slightly larger than the photo. Location of radiocarbon sample SLC-T1-4 is indicated on the log and photo. 


\begin{tabular}{|c|c|c|c|c|c|}
\hline $\begin{array}{l}\text { Radiocarbon } \\
\text { Sample }\end{array}$ & CAMS \# & $14 C \operatorname{Age}^{\mathrm{a}} \pm 1 \sigma$ & $\partial 13 \mathrm{C} \mathrm{Age}{ }^{\mathrm{b}}$ & $\begin{array}{l}\text { Calendar Dates } \\
\text { AD (2бRange) }\end{array}$ & $\begin{array}{c}\text { Calendar Dates } \\
\text { before } 2002 \text { (2бRange) }\end{array}$ \\
\hline SLC-T1-4 & 144465 & $630 \pm 35$ & -25 & 1290-1400 & $660-550$ \\
\hline
\end{tabular}

Trenches SLC-T2 and SLC-T3 revealed a relatively thicker package of sediment overlying glacial till. Upward fault terminations indicate the occurrence of two to three paleoearthquakes. Analysis by the U.S. Geological Survey of trenches SLC-T2 and SLC-T3 and radiocarbon samples are in progress. The results from the two sites will ultimately provide the first paleoearthquake timing information on this section of the fault.

\section{OFFSET GLACIAL MORAINES, STREAM CHANNELS, AND SECONDARY DEFORMATION}

The Denali fault displaces latest Pleistocene glacial moraines at both the Slate Creek and Boulder Moraine sites (figs. 1 and 2). At the Slate Creek site, directly west of our trenches, long-term geologic slip rates have been evaluated by two separate studies of a right-laterally offset glacial deposit by ${ }^{10} \mathrm{Be}$ surface exposure dating and field measurement of the offset (Matmon and others, 2006; Mériaux and others, 2009). Matmon and others (2006) estimated the offset of the moraine at $144 \pm 14 \mathrm{~m}$ and the age of the deposit at $12.0 \pm 1.3 \mathrm{ky}$. In contrast, Mériaux and others (2009) estimated a snow-corrected mean age for the deposit of $11.7 \pm 1.4 \mathrm{ky}$ and inferred secondary offset along subparallel strands north of the fault to estimate the cumulative offset across the entire zone at $166 \pm 25$ $\mathrm{m}$. These values were used to estimate latest Pleistocene slip rates of $12.0 \pm 1.8 \mathrm{~mm} / \mathrm{yr}$ (Matmon and others, 2006) and $13.6 \pm 3.8 \mathrm{~mm} / \mathrm{yr}$ (Mériaux and others, 2009). These slip rate estimates are slightly higher than the geodetically determined strain accumulation rate of $\sim 9 \mathrm{~mm} / \mathrm{yr}$ (Fletcher, 2002), but to first order are in broad agreement. Both studies indicate a westward decrease in slip rate consistent with westward decreases in both the 2002 earthquake slip and cumulative late Pleistocene offsets (Haeussler and others, 2004; Plafker and Berg, 1994). The persistence of slip rate differences along strike can be indicative of segment boundaries, which can influence models of future earthquake ruptures and seismic hazards assessments. Thus we performed an independent measure of latest Pleistocene offset at the Boulder Moraine site, and revisited the Slate Creek site to evaluate inferred secondary faulting and the difference between the two previously published cumulative offset measurements.

We measured an offset stream channel and offset moraines at the Boulder Moraine site adjacent to the Middle Fork Chistochina River, $\sim 3.4 \mathrm{~km}$ northeast of Trout Lake (figs. 1B and 6A). In this area, the fault is difficult to follow through Holocene boulder moraines, but becomes a prominent trace to the east characterized by offset stream channels, south-facing scarps, and linear valleys that extend across late Pleistocene moraines (fig. 6A). In this area, we observed a prominent right-laterally offset stream channel characterized by an approximately 1-m-high north-side-up scarp across the stream channel (fig. 6B). Plants and soil from the eastern margin of the channel are presently submerged in the stream channel. The displacement of the western margin of the channel measured parallel to the fault is $\sim 5.5 \mathrm{~m}$, similar to the average displacement measured nearby on other features in post earthquake surveys (Haeussler and others, 2004).

We measured cumulative late Pleistocene displacement at the Boulder Moraine site by matching the back side of prominent glacial end moraines across the fault in two different locations (A-A' and B-B', fig. 6A). The amount of offset estimated by projecting the smooth slope of the end moraine into the fault and stretching a tape along the strike of the rupture between correlative moraines is 120 and $128 \mathrm{~m}$ for offsets A-A' and B-B', respectively. The uncertainties in these measurements are not quantified due to the reconnaissance nature of our brief visit, but we conservatively estimate that the error may be up to $\pm 3 \mathrm{~m}$ on each side of our projections and that the cumulative offset is between 114 and $135 \mathrm{~m}$. Figure 7 shows retrodeformation of this section of the fault by about 124 $\mathrm{m}$, which restores the end moraine morphology at both sites. Additional morainal features were found to match 

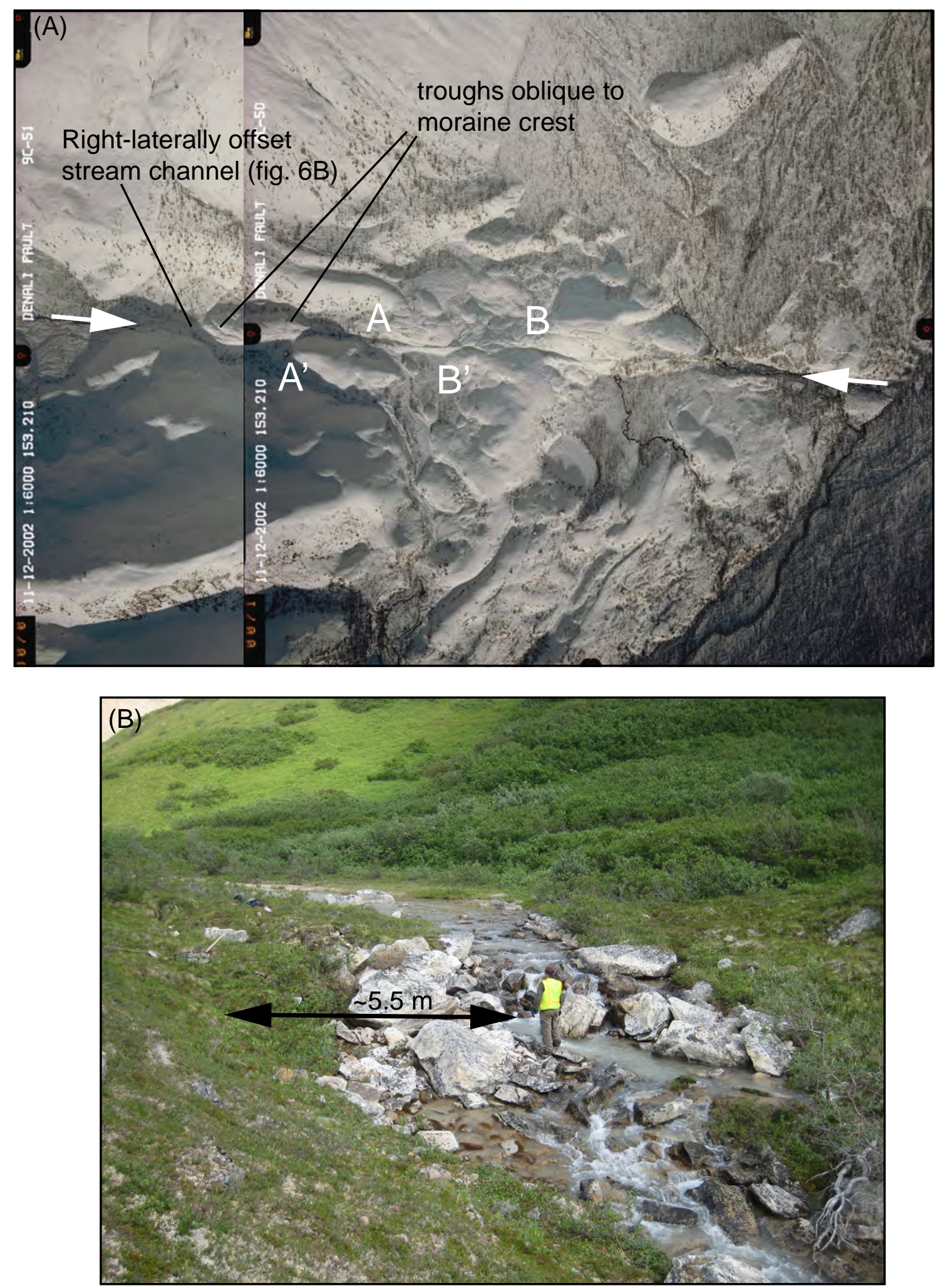

Figure 6. (A) Air photograph of the Boulder Moraine site near the Middle Fork Chistochina River showing location of offset measurements $A-A^{\prime}$ and $B-B$ '. (B) Right-laterally displaced stream channel. 
across the fault after retrodeformation and are shown as white lines on figure 7. Directly west of offset measurement A-A', several subparallel troughs (channels?) trend $160^{\circ}$ across the crest of a lateral moraine that parallels the fault (fig. 6A). These troughs are about $2 \mathrm{~m}$ wide, $1 \mathrm{~m}$ deep, and vegetated. From offset measurement A-A' to the eastern end of the moraine, several scarps extend across the slope of the moraine north of the fault. Lateral offset does not occur across either the troughs or the scarps. Although the origin of these features is inconclusive, we infer that the scarps are gravitational landslide headscarps, and that the troughs may be extensional fractures related to ridgetop shattering during strong ground motions. We cannot preclude other erosional mechanisms (for instance, stream flow) for the origin of the troughs without more thorough investigation.

The lack of cumulative lateral offsets along secondary features indicates that the majority of dextral motion is accommodated by slip on the main strand of the Denali fault at the Boulder Moraine site. The moraines have similar morphology and proximity to the range as the moraines at the Slate Creek site to the west. Thus, assuming an age for the moraines of 9.9-14.1 ky encompassing the range of ages determined to the west by Matmon and others (2006) and Mériaux and others (2009), we calculate a poorly constrained latest Pleistocene slip rate of $8-14 \mathrm{~mm} / \mathrm{yr}$. This rate is similar to that estimated by the Matmon and others (2006) and Mériaux and others (2009) studies, but detailed topographic surveys and additional dating of the offset features are necessary to further substantiate our observations.

At the Slate Creek site, we revisited escarpments and surface ground cracks north of the main trace of the Denali fault that have been inferred by Mériaux and others (2009) to be secondary faults that record cumulative displacement. Cracks north and south of the fault observed in air photos taken immediately after the 2002 earthquake are shown in figure 8 . In the field, these cracks exhibit normal separation and apparent right-lateral displacements of several centimeters to $20 \mathrm{~cm}$. Cracks were observed parallel to the base and across the crest of three scarps that extend across a lateral moraine north of the Denali fault (labeled secondary scarps north, central, and south on fig. 8). The scarps show predominantly normal separation and are characterized by rounded crests and subtle basal depressions. Mériaux and others (2009) assumed the scarps were secondary faults and interpreted a summed lateral offset of $44 \mathrm{~m}$ across the three scarps plus one smaller scarp. To verify these offset measurements in the field, we inspected the eastern margin of a channel that cuts perpendicular to the proposed secondary structures.

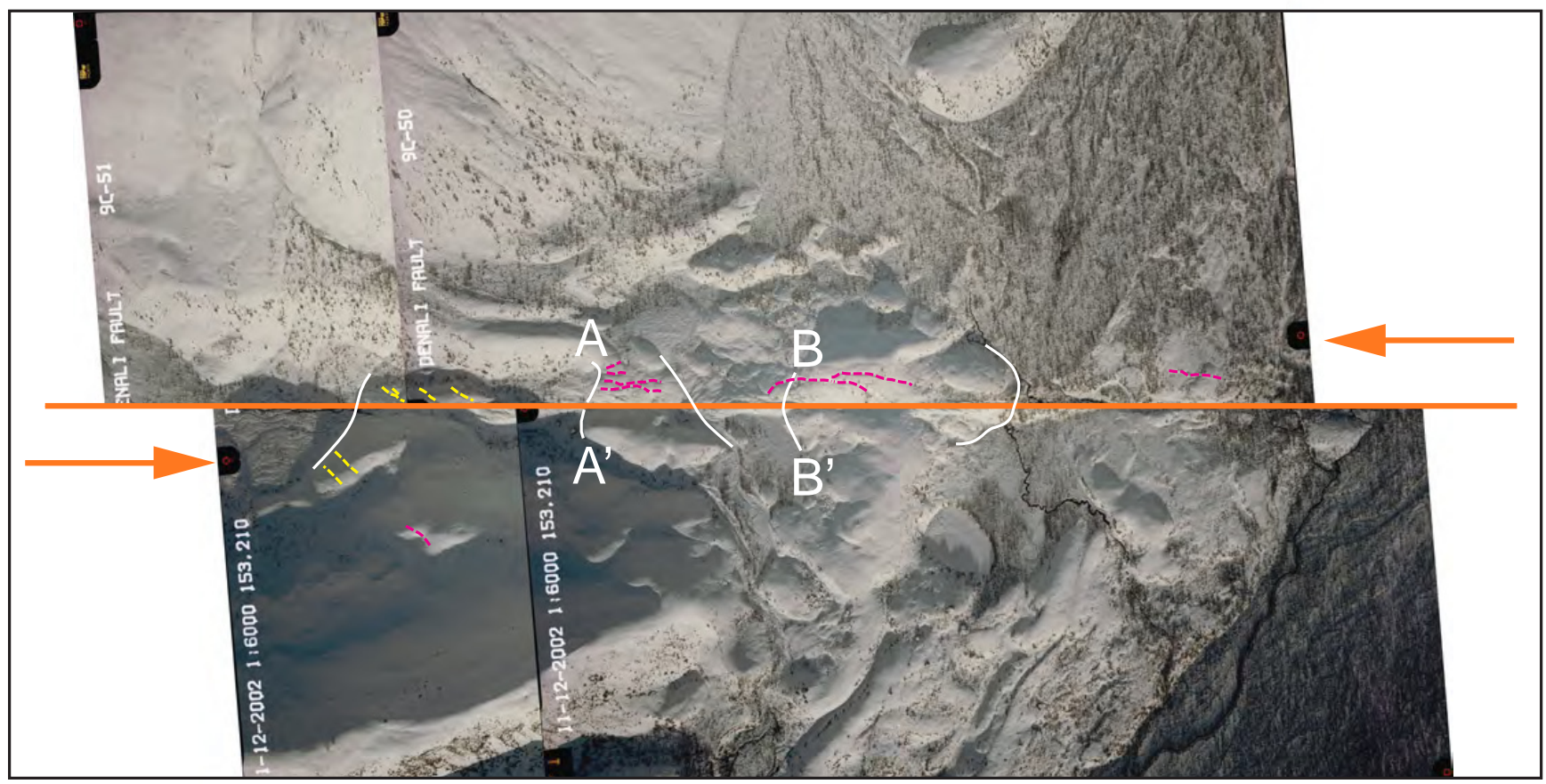

Figure 7. Retrodeformation of offset moraines at the Boulder Moraine site. Red line is Denali fault roughly along the 2002 rupture trace. White lines show prominent morainal features that match across the fault. All of these features are offset a similar amount. Dashed magenta lines indicate surface cracks that may be from strong ground shaking or landsliding. Dashed yellow lines are abandoned troughs along moraine crests that may represent fluvial channels. 


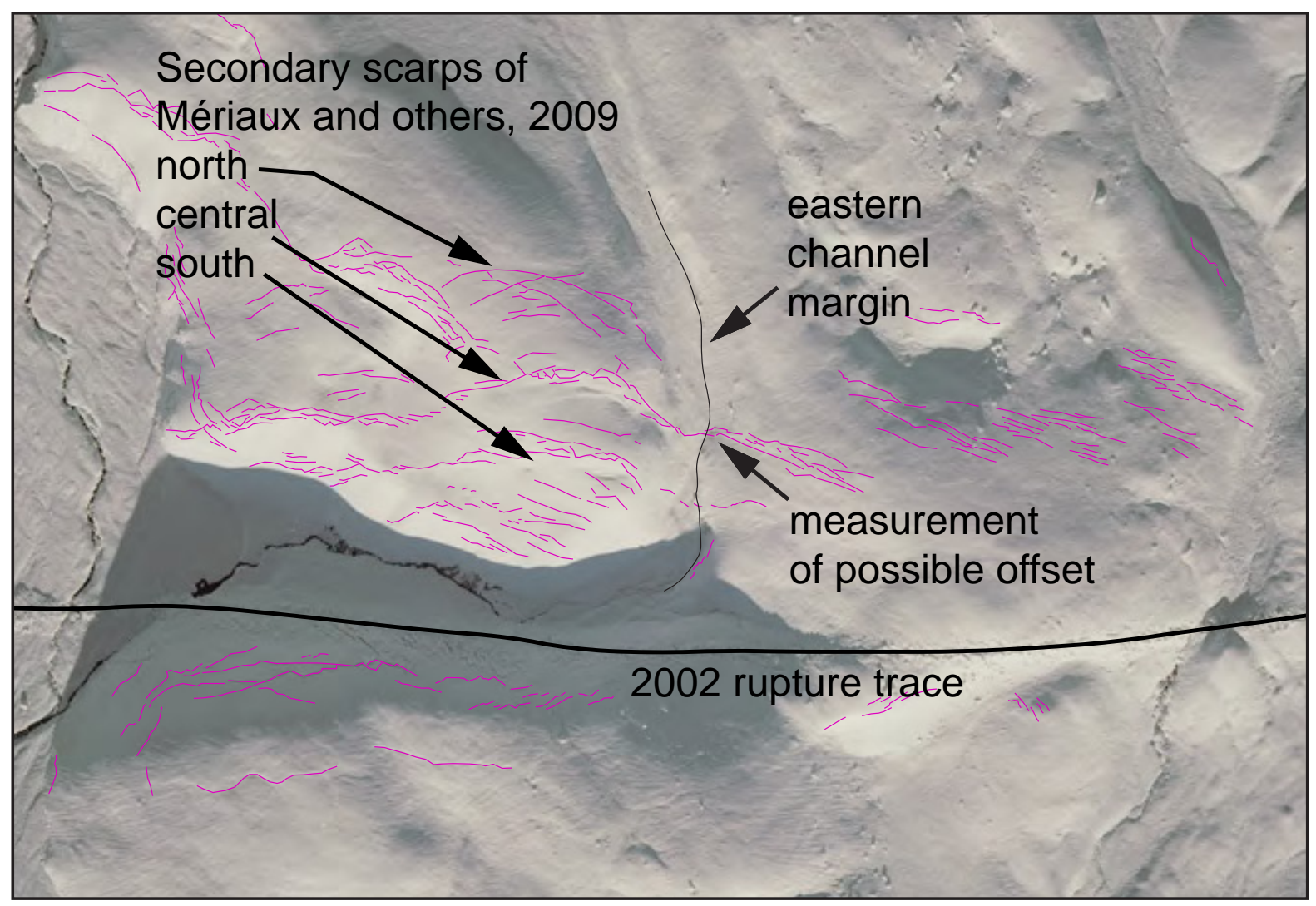

Figure 8. Enlarged photo of western side of the Slate Creek site. Pervasive cracking (traced in magenta) is observed in snow on moraines north and south of the Denali fault trace. Note that not all cracks are marked. The locations of three secondary scarps that cut across a lateral moraine are marked with arrows.

Obvious lateral deflection of the channel is not apparent along the projection of either the north or south proposed secondary faults. The projection of the central proposed secondary fault is coincident with a broad, subtle curvature of the east margin of the channel. Based on projection of the margin of the channel into the central proposed fault, we measured a minimum and maximum possible offset of $2.5 \mathrm{~m}$ and $6.2 \mathrm{~m}$, respectively. This is in contrast to the $19 \mathrm{~m}$ reported by Mériaux and others (2009). Surface ground cracking extends east of the channel, but the scarps are confined to the moraine west of the channel and are not continuous. Thus, it is possible that the deflection is simply coincident with surface ground cracking and reflects natural curvature of the channel margin. Although we cannot demonstrate that the scarps are not secondary faults without a subsurface exposure, our field observations are not consistent with the off-fault cumulative displacements proposed by Mériaux and others (2009). We prefer an alternative explanation for the generation of the scarps by gravitational failure resulting from strong ground shaking, although deflation of the sediments from melting of an ice-cored moraine may have also played a role.

\section{DISCUSSION AND CONCLUSION}

Numerous paleoseismic investigations along the Denali fault since the 2002 earthquake are beginning to illuminate long-term patterns of earthquake recurrence. New radiocarbon dates from trench SLC-T1 contribute to this developing paleoseismic history. The radiocarbon age limits the timing of a paleoearthquake in the Chistochina Glacier area to after 1290-1400 AD, equivalent to after 550 to 660 yr b02. Schwartz and others (2003) and Plafker and others (2006) report the occurrence of an earthquake along the 2002 rupture trace sometime between 340 and 590 yr b02 (228-538 Yr BP) and between 362 and 512 yr b02 (310-460 yr BP), respectively, consistent with our result. It is likely that there have been additional older, surface-rupturing earthquakes along the Denali fault that are not apparent at the Slate Creek site due to either the thin package of sediments or destruction by more recent events. We found no evidence for the 1912 earthquake, observed by Carver and others (2004) at the Delta River $\sim 20 \mathrm{~km}$ west of our site, which suggests that event did not propagate to the Chistochina Glacier area. 
A reconnaissance survey of offset late Pleistocene moraines at the Boulder Moraine site limits the right-lateral offset to about 114-135 m. Although detailed surveying is necessary to more accurately constrain the offset, clear geomorphic features on both sides of the fault do not show evidence of displacement on secondary structures and thus the offset represents a first-order estimate of the latest Pleistocene displacement on the main strand of the Denali fault. Numerical ages do not exist for the moraines at the Boulder Moraine site. Ages on similar moraines at the Slate Creek site to the west suggest the moraines were deposited around 9.9-14.1 ky (Matmon and others, 2006; Mériaux and others, 2009). Using this age range yields a minimum latest Pleistocene slip rate of 8-14 mm/yr.

At the Slate Creek site, we found inconclusive evidence for cumulative tectonic offsets on proposed secondary faults north of the main Denali fault and suggest that the origin for several local scarps is some combination of ground cracking, landsliding, sackung formation, or original ice-melt morphology. Although we did not perform an independent measure of the offset on the main trace of the fault at Slate Creek, we found the offsets on secondary structures to be a negligible contribution to the total offset. Additionally, the offset reported by Mériaux and others (2009) for only the main trace of the fault $(122 \pm 5 \mathrm{~m})$ is similar to the offset measured at the Boulder Moraine site in this study. The slip rates reported by Matmon and others (2006) and Mériaux and others (2009) are indistinguishable within error; however, Mériaux and others (2009) use a cumulative offset including secondary fault offsets $(44 \mathrm{~m})$ that are not supported by our field observations. Based on our offset measurement at the Boulder Moraine site and observations at both the Slate Creek and Boulder Moraine sites that suggest minimal off-fault cumulative tectonic offset, we infer that offset measured along the main trace of the fault is more representative of the long-term cumulative displacement and more appropriate for use in slip rate calculations. Thus, our documentation of offset latest Pleistocene moraines and slip rate estimate at the Boulder Moraine site is similar to slip rates reported by Matmon and others (2006) and Mériaux and others (2009), respectively. However, we infer that the rate is closer to the lower end of the two studies and similar to the $9 \mathrm{~mm} / \mathrm{yr}$ of strain accumulation measured geodetically across the fault (Fletcher, 2002). The results are consistent with the Denali fault accommodating a major portion of right-lateral shear associated with the counterclockwise rotation of the Wrangell block relative to the Northern Cordillera.

The studies described in this report provide the first data on the timing of paleoearthquakes along the central Denali fault and serve as a starting point for understanding the fault's recurrence behavior. Future paleoseismic studies focused on obtaining earthquake timing data on the Susitna Glacier fault will help understand the interaction of master strike-slip faults and secondary thrust faults. Additional paleoseismic data will also help determine whether or not the 2002 rupture section acts as a discrete segment and whether other combinations of faults can rupture in similar-sized events.

\section{ACKNOWLEDGMENTS}

This project was jointly sponsored by the Alaska Airborne Geophysical/Geological Mineral Inventory Program (which is funded by the Alaska State Legislature and managed by the State of Alaska, Department of Natural Resources, Division of Geological \& Geophysical Surveys) and the U.S. Geological Survey. Partial funding for the geologic mapping and analyses was also provided through the State of Alaska General Fund and the U.S. Geological Survey STATEMAP Program under award number 09AC00177. Manuscript reviews by Rich Briggs and Sean Bemis improved the content. We are grateful for assistance from Tom Richardson in the hand excavation of trenches and bear patrol during the summer of 2009. Bill Snider of Coastal Helicopters expertly transported us between the field sites and our camp at Paxson Lodge.

\section{REFERENCES}

Begét, J.E., Reger, R.D., Pinney, D.S., Gillispie, Tom, and Campbell, K.M., 1991, Correlation of the Holocene Jarvis Creek, Tangle Lakes, Cantwell, and Hayes tephras in south-central and central Alaska: Quaternary Research, v. 35, no. 2, p. 174-189.

Biggs, Juliet, Wright, Tim, Lu, Zhong, and Parsons, Barry, 2007, Multi-interferogram method for measuring interseismic deformation-Denali fault, Alaska: Geophysical Journal International, v. 170, p. 1,165-1,179.

Capps, S.R., 1912, The Bonnifield region, Alaska: U.S. Geological Survey Bulletin 501, 64 p., 2 sheets, scale 1:250,000.

Carver, G.A., Plafker, George, Metz, M.C., Cluff, Lloyd, Slemmons, Burt, Johnson, Elden, Roddick, Jim, and Sorensen, Steve, 2004, Surface rupture on the Denali fault interpreted from tree damage during the 1912 Delta River $M_{w}$ 7.2-7.4 earthquake-Implications for the 2004 Denali fault earthquake slip distribution: Bulletin of the Seismological Society of America, v. 94, no. 6B, p. S58-S71. 
Crone, A.J., Personius, S.F., Craw, P.A., Haeussler, P.J., and Staft, L.A., 2004, The Susitna Glacier thrust faultCharacteristics of surface ruptures on the fault that initiated the 2002 Denali fault earthquake: Bulletin of the Seismological Society of America, v. 94, no. 6B, p. S5-S22.

Eberhart-Phillips, Donna, Haeussler, P.J., Freymueller, J.T., Frankel, A.D., Rubin, C.M., Craw, P.A., Ratchkovski, N.A., Anderson, Greg, Carver, G.A., Crone, A.J., Dawson, T.E., Fletcher, Hilary, Hansen, Roger, Harp, E.L., Harris, R.A., Hill, D.P., Hreinsdottir, Sigrun, Jibson, R.W., Jones, L.M., Kayen, R.E., Keefer, D.K., Larsen, C.F., Moran, S.C., Personius, S.F., Plafker, George, Sherrod, B.L., Sieh, Kerry, Sitar, Nicholas, and Wallace, W.K., 2003, The 2002 Denali fault earthquake, Alaska-A large magnitude, slip-partitioned event: Science, v. 300, p. 1,113-1,118.

Fletcher, H.J., 2002, Crustal deformation in Alaska measured using the Global Positioning System: Fairbanks, Alaska, University of Alaska Fairbanks, Ph.D. dissertation, 135 p.

Frankel, Arthur, 2004, Rupture processes of the M7.9 Denali fault, Alaska earthquake-Subevents, directivity, and scaling of high-frequency ground motions: Bulletin of the Seismological Society of America, v. 94, no. 6B, p. S234-S255.

Grantz, Arthur, 1966, Strike-slip faults in Alaska: U.S. Geological Survey Open-File Report 66-53, 82 p.

Haeussler, P.J., 2008, An overview of the neotectonics of interior Alaska-Far-field deformation from the Yakutat Microplate collision, in Freymueller, J.T., Haeussler, P.J., Wesson, R.L., and Ekstrom, Goran, eds., 2008, Active tectonics and seismic potential of Alaska: American Geophysical Union, Geophysical Monograph 179, p. 83-108.

Haeussler, P.J., Schwartz, D.P., Dawson, T.E., Stenner, H.D., Lienkaemper, J.J., Sherrod, Brian, Cinti, F.R., Montone, Paola, Craw, P.A., Crone, A.J., and Personius, S.F., 2004, Surface rupture and slip distribution of the Denali and Totschunda faults in the 3 November 2002 M7.9 earthquake, Alaska: Bulletin of the Seismological Society of America, v. 94, no. 6B, p. S23-S52.

Hickman, R.G., Craddock, C., and Sherwood, K.W., 1977, Structural geology of the Nenana River segment of the Denali fault system, central Alaska Range: Geological Society of America Bulletin, v. 88, p. 1,217-1,230.

Ji, C., Helmberger, D.V., and Wald, D.J., 2002, Preliminary slip history of the 2002 Denali earthquake: EOS Transactions, American Geophysical Union, v. 83, Fall Meeting Supplement, Abstract S72F, 1344.

Lanphere, M.A., 1978, Displacement history of the Denali fault system, Alaska and Canada: Canadian Journal of Earth Sciences, v. 15, p. 817-822.

Lowey, G.W., 1998, A new estimate of the amount of displacement on the Denali fault system based on the occurrence of carbonate megaboulders in the Dezadeash Formation (Jura-Cretaceous), Yukon, and the Nutzotin Mountains Sequence (Jura-Cretaceous), Alaska: Bulletin of Canadian Petroleum Geology, v. 94, p. 4,333-4,359.

Matmon, A., Schwartz, D.P., Haeussler, P.J., Finkel, R., Lienkaemper, J.J., Stenner, H.D., and Dawson, T.E., 2006, Denali fault slip rates and Holocene-late Pleistocene kinematics of central Alaska: Geology, v. 34, p. $645-648$.

Mériaux, A.S, Sieh, Kerry, Finkel, R.C., Rubin, C.M., Taylor, M.H., Meltzner, A.J., and Ryerson, F.J., 2009, Kinematic behavior of southern Alaska constrained by westward decreasing postglacial slip rates on the Denali Fault, Alaska: Journal of Geophysical Research, v. 114, B03404, doi:10.1029/2007/JB005053.

Nokleberg, W.J., Jones, D.L., and Silberling, N.J., 1985, Origin and tectonic evolution of the Maclaren and Wrangellia terranes, eastern Alaska Range, Alaska: Geological Society of America Bulletin, v. 96, p. 1,251-1,270.

Personius, S.F., Crone, A.J., Burns, P.A., Begét, J.E., Seitz, G.G., and Bemis, S.P., 2010, Logs and geologic data from a paleo-seismic investigation of the Susitna Glacier fault, central Alaska Range, Alaska: U.S. Geological Survey Scientific Investigations Map 3114, 2 sheets, http://pubs.usgs.gov/sim/3114/.

Plafker, George, and Berg, H.C., 1994, Review of the geology and tectonic evolution of Alaska, in Plafker, George, and Berg, H.C., eds., The Geology of Alaska: Boulder, Colorado, Geological Society of America, The Geology of North America, v. G-1, p. 989-1,021.

Plafker, George, Carver, G.A., Cluff, Lloyd, and Metz, Mike, 2006, Historic and paleo-seismic evidence for noncharacteristic earthquakes and the seismic cycle at the Delta River crossing of the Denali fault, Alaska [abs.]: 102nd Annual Meeting of the Cordilleran Section, Geological Society of America, May 8-10, Anchorage, Alaska, v. 38, 96 p.

Plafker, George, Hudson, Travis, and Richter, D.H., 1977, Preliminary observations on late Cenozoic displacements along the Totschunda and Denali fault system, in Blean, K.M., ed., the United States Geological Survey in Alaska: Accomplishments during 1976, U.S. Geological Survey Circular 751-B, p. B67-B69.

Richter, D.H., and Matson, N.A., Jr., 1971, Quaternary faulting in the eastern Alaska Range: Geological Society of America Bulletin, v. 82, p. 1,529-1,540. 
Ridgway, K.D., Thoms, E.E., Layer, P.W., Lesh, M.E., White, J.M., and Smith, S.V., 2007, Neogene transpressional foreland basin development on the north side of the central Alaska Range, Usibelli Group and Nenana Gravel, Tanana basin, in Ridgway, K.D., Trop, J.M., Glen, J.M.G., and O’Neill, J.M., eds., Tectonic growth of a collisional continental margin - Crustal evolution of southern Alaska: Boulder, Colo., Geological Society of America Special Paper, v. 431, p. 507-547.

Riehle, J.R., 1994, Heterogeneity, correlatives, and proposed stratigraphic nomenclature of Hayes tephra set HAlaska: Quaternary Research, v. 41, p. 285-288.

Reimer, P.J., Baillie, M.G.L., Bard, Edouard, Bayliss, Alex, Beck, J.W., Blackwell, P.G., Bronk Ramsey, C., Buck, C.E., Burr, G.S., Edwards, R.L., Friedrich, M., Grootes, P.M., Guilderson, T.P., Hajdas, I., Heaton, T.J., Hogg, A.G., Hughen, K.A., Kaiser, K.F., Kromer, Bernd, McCormac, F.G., Manning, S.W., Reimer, R.W., Richards, D.A., Southon, J.R., Talamo, Sahra, Turney, C.S.M., van der Plicht, Johannes, Weyhenmeyer, C.E., 2009, IntCal09 and Marine09 Radiocarbon Age Calibration Curves, 0-50,000 Years cal BP, Radiocarbon, vol. 51, no. 4, p.1,111-1,150.

Schwartz, D.P., 2006, A look back at 1906-Perspectives on great earthquakes and post-earthquake investigations: Seismological Research Letters, v. 77, no. 2, p. 123-127.

Schwartz, D.P., and the Denali fault earthquake geology working group, 2003, Paleo-earthquakes on the DenaliTotschunda fault system-Preliminary observations of slip and timing: American Geophysical Union, fall meeting, abstract \# S11B-03.

St. Amand, Pierre, 1957, Geological and geophysical synthesis of the tectonics of portions of British Columbia, the Yukon Territory, and Alaska: Geological Society of America Bulletin, v. 68, no. 10, p. 1,343-1,370.

Stuiver, Minze, and Polach, Henry A., 1977, Discussion-Reporting of ${ }^{14} \mathrm{C}$ Data: Radiocarbon, v. 19, no. 3, p. 355-363.

Taylor, M.H., Leprince, Sebastien, Avouac, J.P., and Sieh, Kerry, 2008, Detecting co-seismic displacements in glaciated regions-An example from the great November 2002 Denali earthquake using SPOT horizontal offsets: Earth and Planetary Science Letters, v. 270, p. 209-220.

Thoms, E.E., 2000, Late Cenozoic unroofing sequence and foreland basin development of the central Alaska RangeImplications from the Nenana Gravel: Fairbanks, Alaska, University of Alaska Fairbanks, M.S. thesis, 215 p.

Wahrhaftig, Clyde, 1958, Quaternary geology of the Nenana River valley and adjacent parts of the Alaska Range, in Wahrhaftig, Clyde, and Black, R.F., eds., Quaternary and engineering geology in the central part of the Alaska Range: U.S. Geological Survey Professional Paper 293, p. 1-68.

Wahrhaftig, Clyde, Wolfe J.A., Leopold, E.B., and Lanphere, M.A., 1969, The coal-bearing group in the Nenana coal field, Alaska: U.S. Geological Survey Bulletin 1274-D, 30 p. 



\section{APPENDIX A}

Stratigraphic unit descriptions for trench SLC-T1 (figs. 4 and 5).

\section{Unit Descriptions}

Peat, black and compact at base, grading upward

7 - to light brown, fibrous, coarse peat. Thin and weakly developed above unit 6 .

6 - Sand and gravel, loose, poorly sorted; colluvium derived from units 2 and 3, or disrupted units 2 and 3.

5 - Buried peat, black and compact at base, grading upward to light brown, fibrous, coarse peat; plants in growth position are buried below the fault tip.

4 - Angular cobbles, clast supported, voids between clasts; lag cobbles or frost heave.

3 - Fine- to medium-grained sand with trace gravel, well sorted, that fines upward to fine sand and silt with thin laminae.

2 - Coarse sand and

1 - Clayey sand with gravel; glacial till. 